\title{
The private company in Spanish law
}

\author{
by Frank Wooldridge
}

\begin{abstract}
An examination of the Sociedad de Responsabilidad Limitada (RL or SL), which came into force in 1995, and the newer Sociedad Limitada Neuva Empresa (SNLE) which was introduced in 2003.
\end{abstract}

\section{INTRODUCTORY REMARKS}

$\mathrm{T}$ he private limited liability company (Sociedad de Responsabilidad Limitada _ SRL or SL) is the most commonly used business entity in Spain. It is governed principally in that country by Law No 2/1995, which came into force on the June 1 of that year. A new type of limited liability company was introduced in 2003, the Sociedad Limitada Neuva Empreseas (SNLE), which has apparently not been very widely used. This type of entity will be mentioned in this article, which is principally concerned with the older form of private limited liability company.

The shares in an SL cannot be represented by share certificates or by entries in an account. They are not treated as negotiable securities, and are called participaciones (participations or quotas) to distinguish them from the shares in a public company, which are called acciones. The same is true in the case of shares in a French SARL or a German GmbH.

As is the case with the latter entities, the Spanish private company is intended to be of a closely held character. Thus it follows from Article 29(1) or Law No 2/1995 that unless the company's articles provide otherwise, shares are freely transferable between members, or to members' spouses, ascendants or descendants, or to companies in the same group as that in which the shares are held. In other cases, unless the articles otherwise provide, the transfer of shares is subject to the rules providing for pre-emptive rights contained in Article 29(2). The person wanting to transfer his or her shares must notify the management body of the company, mentioning the number and characteristics of the shares, the identity of the proposed purchaser, and the price and other particulars of the proposed transfer. Such a transfer requires the consent of the other members, which has to be given by the general meeting. If such consent is refused, the management body is required to inform the intending transferor of the identity of one or more members, or third parties who are willing to acquire all the relevant shares by means of a notarial act, but this is unnecessary if the intending transferor participated in the relevant general meeting. If no such person wishes to purchase the shares, the company itself may do so, if necessary by means of a reduction of capital if the relevant procedures have been carried out without success, a sale to the proposed transferee is permissible. Such a sale may also take place if the intending transferor does not receive notice of the identity of any purchaser or purchasers within three months of the time when the company was notified of he offer (Art 29(2)(f) of the Law No 2/1995). These complex provisions governing the pre-emptive rights of shareholders exemplify the personalistic nature of the Spanish private company. This is also illustrated by the fact that that, in common with private company in many other European countries, the Spanish private company may not issue bonds (Art 9, ibid).

The above rules help to distinguish the Spanish private company from the Spanish public company (Sociedad Anonima, SA). The private company is also distinguished from the latter entity by reason of the fact that no independent valuation of contributions in kind is required. An adequate description of such contributions in the deed of incorporation is sufficient. However, it follows from Article 21(1) of Law No 2/1995 that the founding members are jointly and severally liable to the company and its creditors for the genuineness of such contributions. When a capital increase takes place, the directors of the company are jointly and severally liable to the company and its creditors for the difference between the value of the contributions in kind stated in the report they are required to make in accordance with Article 74(3) and their actual value. The present rule may sometimes result in unfortunate consequences for creditors and shareholders, but will expedite the formation of the company and save expenditure on the appointment of an expert valuer.

\section{FORMATION OF THE COMPANY}

The name of an SL has to be reserved in advance. The Central Commercial registry decides on the availability of the names and problems sometimes arise in relation to this 
matter. If the name is available, a certificate of availability is given by the Registry stating that the name has been reserved. The period of reservation will be fifteen months. The certificate of availability given by the Registry denotes that the name has been reserved, and is valid for two months. It may be renewed until the 15 month period has elapsed.

The deed of incorporation must be executed by all the founder members or their representatives; the members must take up and pay for all the shares in the company. The required contents of the deed of incorporation are set out in Article 12 of the Law No 2/1995. It must mention the identity of the single member (if there is one) or members, state the members' intention of forming the SL and give particulars of their contribution. It must also state the precise manner in which the administration of the company will be initially carried out if the articles permit alternative forms of management. Furthermore, it must contain the names of the persons who will be actually charged with the management of the company, and also mention any supplementary agreements concluded by the members in addition to the articles. Such arguments must not conflict with the general law, or the basic rules governing the SL.

The minimum required contents of the articles are set out in Article 13 of Law No 2/1995, and include the company's name, its objects, the date of closure of its financial year, its registered office (domicile social), particulars of its capital, and the method or methods of providing for its management. The minimum capital on incorporation is $£ 3,012$ unless the articles provide otherwise, the company may commence business once the deed of incorporation has been prepared by the required notary public. The company does not acquire legal personality until it is entered in the commercial register of the place of its registered office.

The incorporation of an SL is subject to a tax on the subscribed capital and any issue premium. The duration of an SL is for an indefinite period, unless the articles otherwise provide (Art 14(2) ibid). According to Article 7 of Law No 2/1955 the registered office of the company must be at the place where the company has its headquarters or where its principal place of business is situated: these must be in Spain. It appears that the location cannot be transferred outside Spain, except where an international treaty so permits. This position may well be modified by future Community legislation and is doubtfully compatible with Community law in its present state.

\section{RULES GOVERNING SHARES AND CAPITALISATION}

The share capital of an SL is divided into quotas, which have been called shares in this article. As in the case of France, Germany, Italy and Belgium, such shares cannot be listed on the stock exchange and are not considered to be investment securities. The shares (or quotas) held by each member are registered in the register of members maintained by the managers. Shares may be divided into different classes, which confer different rights as to dividends or voting. Voteless shares are sometimes used.

Certain important rules relating to the transfer of shares have already been mentioned above. The transfer of shares in an SL has to be carried out by means of a notarial act, and must be entered in the register of members before the transferee may be recognised as a member (Arts 26(1) and $27(1), i b i d)$. It is thus necessary for the director or the company secretary to be notified of the transfer. As indicated above, certain kinds of share transfers are made subject to the pre-emptive rights of the other members, unless the articles otherwise provide. Special rules are made applicable to obligatory transfers at public auctions and to the acquisition of shares by reason of the succession of an heir (transmission mortis causa) (Arts 31 and 32 ibid).

As in the United Kingdom, shares may not be issued at a discount, and shareholders may not be released from their obligation to pay their contributions. Dividends are only payable out of the profits for the financial year or out of free reserves if the net book value of the assets of the company is not less, and will not become less by reason of the distribution, than the share capital. As is also the case with the public company (SA), a minimum legal reserve has to be maintained while the company is in existence. At least 10 per cent of the profits have to be applied to the legal reserve until it reaches 20 per cent of the share capital. Until it reaches this amount, it can only be used to offset losses where there are insufficient other reserves which may be employed for this purpose.

As is the case in a number of other jurisdictions, an SL cannot subscribe for its own shares, or shares issued by its parent company. It may acquire its own shares, or those of its parent company in a limited number of circumstances. It may do so where such shares constitute a part of assets acquired gratuitously as a whole on a universal transfer, or which are acquired by reason of a court order in settlement of a claim by the company against the holder of such shares. Furthermore, the company may acquire its own shares in consequence of a resolution for the reduction of its share capital. It may in addition acquire its own shares as the result of legal or administrative execution proceedings (Art 40(1)(a)-(c) of Law No 2/1995). When a company acquires its own shares these must be transferred within a maximum period of three years; shares acquired in a parent company must be transferred within the period of one year. Whilst the treasury shares remain in the company's possession, the voting rights attaching to them are suspended for the relevant periods. According to Article 40(5), an SL may not advance funds, grant loans, give guarantees, or facilitate any form of financial assistance for the acquisition of its own shares, or for the shares issued by a company in the same group to which it belongs. 


\section{THE GENERAL MEETING}

It follows from Article 44 that the general meeting (Junta General) has very wide competences concerning the structure, functioning and transformation of the company. It is convened by means of a notice published in BORME (Buletin Oficial del Registro Mercantil) as well as in one of the daily newspapers having a large circulation distributed in the town or city in which the company has its registered office (Art 46(1) ibid). The articles may however provide for another method of notification, for example through the medium of a particular newspaper, or by means of any other individual written communication process which assures the reception of the notice by all the members. This process may for example be registered mail or fax (Art 46(2) ibid.). At least 15 days notice must be given of the meeting (Art 46(3) ibid).

Unless the articles provide otherwise, the meeting will be held in the town or city where the company has its registered office. If a meeting place is not specified, it shall be assumed that the meeting is to take place at the corporate headquarters (domicilio social) (Art 47, ibid). As is the case with the public company, Law No 2/1995 recognises the universal general meeting (junta universal) without any requirement for notification at any time and place, which may be outside Spain, provided that all the members agree to constitute the meeting and on its agenda. Such a meeting may concern itself with any matter (Art 48, ibid).

All the members have the right to attend the general meeting, and the articles cannot require a minimum shareholding for attendance thereat (Art 49(1), ibid). According to Article 52, a member may not exercise a vote in relation to certain issues which personally affect him. Thus he or she cannot vote when a decision is being made authorising the member to transfer his or her shares; or to expel him or her from the company; or to free him or her from an obligation; or grant him or her a right; advance him or her funds; or grant him or her credits or loans; or offer him or her guarantees, or financial assistance. He or she cannot vote if being a director the decision concerns the prohibition of competition, or the establishment of a relationship with the company which involves providing him or her with any kind of work or services (Art 52, ibid).

An SL takes decisions by a majority of the validly cast votes, provided they represent at least one third of the votes attached to the company's shares. However certain important decisions may only be taken by an enhanced majority of the votes attaching to the shares. These include alteration of the articles; the exclusion of the preferential right of subscription on an increase of capital; and the conversion of the company into an enterprise of a different kind, its merger with another company, or its division. The first type of operation requires an absolute majority of the votes cast in respect of the shares, whilst the other ones require a two thirds majority (Art $53 \mathrm{ibid}$ ). According to
Article 53(3), for all or certain matters the articles may require a majority superior to that required by law, but may not require unanimity.

\section{MANAGEMENT}

The different methods of managing an SL are set out in Article 57 of Law No 2/1995. The management of an SL may be conferred on a sole director, or on two directors acting together or separately, or on a board of directors consisting of not less than three and not more than 12 persons. When such a board is set up, its powers of representation can, according to Article 62(2)(d) be delegated to one or more members of the board, or in favour of an executive committee (Comissión ejecutiva). However the directors may not delegate their duty to lay the amounts and balance sheets before the general meeting, or the power granted to them by the general meeting, unless such delegation was specifically authorised by the general meeting. This rule also applies to the SA (public company).

The company's articles may provide for more than one form of management. If this is the case, the general meeting may choose any of these forms, and change from one form to another without amending the articles (Art 57(2) of Law No 2/1995. The responsibilities of the directors of an SL are largely governed by the rules applicable to the directors of an SA (Art 69(1), ibid). The directors represent the company and are required to carry out their tasks with the diligence of a competent businessman and a loyal representative and in accordance with the law and the articles (Art 69(1), ibid). The directors have certain specific tasks other than that of representing the company. They are thus responsible for the establishment of the accounts, which are largely governed by chapter VII of the law governing the SA. Such establishment must take place within three months of the end of the relevant financial year, and must also include the management report and the proposal for the application of the profits. Director and officer insurance is permissible and is common in Spanish companies.

Furthermore, the directors are required to call general meetings of the company within the first six months of each financial year (Art 45(2) ibid). If the general meeting is not convened when necessary, the Court of First Instance of the place where the registered office is situated may call it on the application of the holders of at least 5 per cent of the company's capital (Art 45(3) ibid). In addition, the directors are under a duty to apply for insolvency proceedings (disolution judicial) when the members have failed to do so (Art 105(4) ibid.). If they had to do so, they are made jointly and severally liable for all the company's debts (Art 105(5) ibid).

The directors are jointly and severally liable to the company, its members and creditors for any damage they may cause by acts done by them or resolutions passed which infringe the law or contravene the articles, or if they 
have not carried out their duties with the proper degree of diligence, or have failed to act in the best interests of the company. Thus, if the company has a board of directors, all the directors who have been responsible for such an action or resolution will be jointly and severally liable to the company for the damage caused by it. Directors may be exonerated from such liability if they can show that they did not take part in the adoption of the particular action or resolution, or its execution, were unaware of its existence or, if they were so aware, they did everything possible to avoid the damage, and at the very least they expressed their opposition to it. The company's action against the directors will be initiated by a resolution of the general meeting, which may compromise or waive the right to bring the action, provided that shareholders representing at least 5 per cent of the capital did not vote against such compromise or waiver.

Shareholders and third parties, including creditors, may bring an action (which will be based on tort) for damage suffered in consequence of their conduct. The liability of directors towards the company, its members and third parties will not necessarily be excluded where the particular board resolution or action which is incompatible with the company's articles, or in breach of their duty of care, has been approved in advance or been ratified by a further company resolution. Members who voted against such a harmful resolution are excluded from such liability, but the same does not seem to be true of members who simply abstained from voting.

According to Article 42 of Law No 2/1995, if the company infringes the requirements imposed on it by Article 40 concerning the purchase of its own shares and/or financial assistance for such purchase, the directors of the company will be treated as being liable for the infringement, and will be subject to a fine, after the matter has been investigated by the Ministry of the Economy and Finance (Ministerio de Economia y Hacienda). The sanctions expire after a period of three years.

\section{ACCOUNTS AND REPORTS}

As already explained, the principal provisions governing the accounts of a private company (SL) are contained in Chapter VII of the law governing public companies of 1989, as amended, to which Article 84 of Law No 2/1995 makes reference. The latter law contains only one further provision concerning the accounts, Article 86. The latter article provides that after the general meeting has been called, any member can obtain a copy of the documents which have to be approved by it as well as a copy of the directors and auditors' reports without payment and without delay. During the same period, and unless there is a provision to the contrary in the articles, a member or members who hold at least 5 per cent of the share capital, can examine supporting documents and preceding accounts at the registered office of the company, either by himself or with the assistance of an expert.
The annual accounts are comprised of the balance sheet, the profit and loss account and the annual report. The directors have to prepare draft financial statements comprising the three aforementioned matters, and also the management report and the proposed distribution of profits or losses. A summary balance sheet is available to those companies which comply for two consecutive years as of the last day of each financial year, with at least two of the three following criteria:

(i) the total value of the assets does not exceed $€ 2,374,000$;

(ii) the net value of the annual turnover does not amount to $€ 4,747,996$; and

(iii) the average number of employees during this financial year does not exceed 50.

In addition, certain companies may present an abridged profit and loss account provided that they comply for two consecutive years as of the last day of each financial year, with at least two of the following criteria:

(i) the total value of the assets does not exceed $€ 9,495,992$;

(ii) the net amount of the annual turnover is less than $€ 18,991,983$ and

(iii) the average number of employees during the financial year does not exceed 50.

Companies which are entitled to produce a summary balance sheet may establish a summary annual report in accordance with the provisions of section 201 of the Act of 1989 (as amended) governing the SA. The annual report complements, elucidates, and makes observations on the balance sheet and profit and loss account. If a company is permitted to prepare a summary balance sheet, it is not required to prepare any management report whatsoever, or to audit its accounts.

\section{WITHDRAWAL AND EXCLUSION OF MEMBERS}

The possibility of a member withdrawing from the company or being excluded therefrom, which is regulated by Chapter IX of Law No 2/1995, is another characteristic which helps to distinguish the SL from the SA. These possibilities also exist in German private companies. According to Article 95 of Law No 2/1995, members who have not voted in favour of certain actions by the company may withdraw from it. These include the substantial alteration of the articles; the transfer of the registered office abroad where this is permitted under an international treaty in force in Spain which permits the maintenance of the legal personality of the company; the alteration of the rules governing the transmission of shares; the extension of the life span of the company (which is unlimited if the articles do not provide otherwise); the conversion of the company into an entity of another kind; and the creation, 
modification or abolition in advance of the obligation to provide supplementary contributions (prestaciones accesorias), unless the articles otherwise provide. Such contributions do not form part of the capital of the company, and the provision for them reflects the personalistic nature of the company; they may include the obligation to perform work or services or to make a loan to the company or to pay the interest on a loan made to it. This limitation is inapplicable where a director has been required to indemnify a company in accordance with Article 98.

A person who has not voted in favour of the relevant actions by the company and who opts to withdraw from it will be reimbursed for his shares at an agreed value, or failing that one determined by the company auditor and, in the absence of such an auditor, one designated by the Companies Registry of the place where the registered office is situated (Art 100(1) ibid).

The company is empowered to exclude a member in certain circumstances, which are set out in Article 98(2). These comprise failure of a member to comply with his or her obligation to provide accessory contributions, or a breach by a director of his or her obligation not to compete with the company (see Art 65, ibid), or failure by such a director to indemnify the company for damages caused to it by actions contrary to Law No 2/1995 or the articles or carried out without due diligence. Such exclusion will necessitate the consent of the general meeting. If a member holds 25 per cent or more of the company's capital, his or her exclusion will require a final court decision, if he or she does not willingly consent to it. This limitation is inapplicable where a director has been required to indemnify a company in accordance with Article 98.

A member who is excluded must receive reimbursement for his shares, which does not remove that member's possible duty to indemnify the company. There is no provision permitting the withdrawal of a member who suffers from oppression, who would seem to be sometimes limited in the recourses open to him. Spanish company law contains no provisions comparable to sections 994 et seq of the UK Companies Act 2006.

\section{CONCLUDING REMARKS}

The above statute is somewhat complex. Compliance with its requirements concerning notarial acts will sometimes prove expensive. The absence of an express recognition of the fiduciary duties of directors may be somewhat surprising, although the situation is the same with the German GmbH; the courts have recognised such duties in Germany. Law No 2/1995 appears not to contain much concerning the protection of minority shareholders. It is perhaps surprising that the provisions relating to supplementary contributions have been retained in Law No 2/1995 and that Spanish company law makes no provision for employee participation.
The provisions governing the giving of financial assistance for the purchase of the company's shares may not be entirely necessary. It is now proposed in the Netherlands that the corresponding provisions of the rules governing the Dutch private limited liability company (besloten vennootschap) contained in Book 2, Article 207c of the Dutch Civil Code should be repealed. However, this Dutch proposal is accompanied by proposed new rules making distributions subject to a liquidity and balance sheet test. Certain provisions of the Spanish Act may no longer be of much practical importance. This may be the case with the provisions relating to the expulsion and withdrawal of members. The 1995 law contains nothing about the resolution of disputes between the members of the company. However, the Act would seem to be a generally well conceived piece of legislation despite its occasionally rather detailed character.

A new type of private limited liability company was introduced as the result of Law No 7/2003 of 2 June 2003, which inserted fifteen new sections, Articles 130-144 into Law No 2/1995. This new law was accompanied by the Order of 4 June 2003, which consists of one article with an annex providing for draft articles of association. The latter are intended as guidelines for the new type of company, giving the parties freedom to establish certain other provisions. Article 1 thereof provides that the name of this new kind of company will have the letters SLNE at the end. Article 2 specifies that the object of the new companies will be one of those set out in Article 132 of Law No 7/2003. Article 3 provides that the company may be set up for a definite or indefinite period and that the company may begin to transfer business as from the date of its incorporation. This corresponds with the present position relating to the SL. Article 4 concerns the company's registered office and also stipulates that the board of directors shall be empowered to create or change the address or subsidiaries, branches or representative offices, both in Spain and abroad. Articles 5 and 6 concern the capital of the company, which is to be denominated into euros and divided into shares of equal value. Article 7 concerns the procedure relating to general meetings, which may be called by registered post or by e-mail to the relevant director's address. Articles 8-10 include the rules governing the board of directors and their power. The company may have a single director or a board, and if it has a board it may be agreed that there shall be joint and several liability. Articles 11 and 12 are concerned with the company's directors, whilst Articles 13 and 14 deal with the liquidation of the company. Article 15 is concerned with dispute resolution and provides that such disputes shall either be resolved by the courts of the place where the registered office is situated or by means of arbitration. This rule would seem to correspond generally with the present situation under Spanish company law.

Law No $7 / 2003$ has the object of simplifying the incorporation procedure for limited companies designed to operate small businesses and, as already indicated contains 
15 new sections. Article 130 stipulates that the new company will be a special type of private company. Article 131 provides for the name applicable to such companies, stipulating that the name shall consist of the two surnames and the first name of one of the founding members followed by the identifying code applicable to the particular company. Article 132 specifies certain objects which may be pursued by the new company, which include agriculture, fishing, transport activities or the provision of professional services. It also provides that the founders may include any other kind of activity, but this will have to be approved by the registrar of companies. Article 133 prescribes that the members shall be not more than five and must consist of natural persons. A person may be the sole shareholder of only one SLNE Article 134 requires incorporation by means of a notarial deed which will require registration. This rule applies at present to the original form of private company, as does the rule in Article 135 which provides that the company acquires legal personality on registration. According to Article 135, the minimum share capital of the company shall be $€ 3,012$ and the maximum shall not exceed $€ 21,202$. The minimum capital may be paid in cash only and there will be no need to have a register of members - shareholder status will be proved by means of the instrument recording the acquisition of shares. Article 138 contains the rules governing the administration of the company and, in particular, those relating to general meetings. Article 139 provides that the management of the company may be carried out by a single director or by a board of directors. Article 140 is concerned with the amendment of the company's articles of association. Article 141 provides for the annual accounts which, it is stipulated, should be prepared by a simplified method. The rules governing shareholders are dealt with in Article 142, whilst Article 143 is concerned with the conversion of the company into an entity of another type, which may be a civil partnership, an SA or ordinary SL, a cooperative or an EEIG. According to Article 144 the new type of limited company may continue to transact business as an ordinary SL, after passing the necessary resolution at a general meeting.

The latter amendments have to be registered at the Companies Registry within two months of the passing of the necessary resolution. A number of additional rules exist, for example one relating to the existence of an electronic document which will contain all the information necessary for the company to comply with social security and tax law. It is rather surprising to note that comparatively little use has been made of the simplified company form, perhaps owing in part to its relative unfamiliarity and the limitations it contains on the company's capital and the size of the membership. However, the older type of private limited liability company remains the most popular type of business entity in Spain. (c)

Dr Frank Wooldridge

\section{Institute Lectures}

\section{Wednesday, 30 January 2008 \\ PROFESSOR DAWN OLIVER}

Professor of Constitutional Law, University College, London The UK constitution in transition: from where to where?

Issues in constitutional law lecture series

Thursday, 31 January

\section{LINDA SIEGELE}

Staff Lawyer, FIELD (Foundation for International Environmental Law \& Development)

How many roads? Negotiating an international access and benefit sharing scheme

Part of a series of lectures organised by the Law, Environment and Development Centre at SOAS in collaboration with the IALS and FIELD

\section{Thursday, 14 February}

\section{DR PHILLIPS CULLET}

Reader in International Environment Law, SOAS

Water law reform, poverty and development: the case of India

Part of a series of lectures organised by the Law, Environment and Development Centre at SOAS in collaboration with the IALS and FIELD

\section{Monday, 18 February \\ CAROLYN SHELBOURN}

School of Law, University of Sheffield

Time crime - criminal law and archaeology: some lessons from the United States?

\section{Wednesday, 20 February}

\section{PROFESSOR ANTHONY BRADLE}

Professor Emeritus of Constitutional Law, University of Edinburgh

Relations between Executive, Judiciary and Parliament: an evolving saga?

Issues in constitutional law lecture series

\section{Thursday, 21 February}

\section{PROFESSOR PATRICIA PARKS}

Professor of Environmental Law, Southampton Solent University

Biofuels, energy security and unintended consequences

Part of a series of lectures organised by the Law, Environment and Development Centre at SOAS in collaboration with the IALS and FIELD 